\title{
Inconsistency of the Regulation of Indemnity Payment as an Asset Recovery in Eradication of Corruption in Indonesia
}

\author{
I Made Hendra Kusuma \\ Faculty of Law \\ Universitas Warmadewa \\ Denpasar-Bali, Indonesia \\ imadehendra1961@gmail.com
}

\begin{abstract}
This paper reviews the inconsistencies in the legal settlement of indemnity payments in accordance with the concept of asset recovery and examines the underlying arrangement of fixed replacement payments in the form of asset recovery without the principals having to be imprisoned. Statute and conceptual approaches to legislation were used in this study. The results indicate that the arrangement of the payment of the replacement money listed in Article 18 paragraph (1) letter b, paragraph (2) and paragraph (3) of Law Number 31 Year 1999 is inconsistent, since the provisions in paragraph 3 ) of the article provides an opportunity to have "option" to reimburse payments in cash with imprisonment and this is not in accordance with the concept of asset recovery. The provisions contained in paragraph 3 shall be deleted and replaced by the provisions of the law which basically specify that substitute payments shall be made until completely closed (not to be replaced by prison), which can be done by seizing and auctioning the defendant property that is clearly known by the prosecutor as the executor, even if the defendant has completed his jail sentence.
\end{abstract}

Keywords-asset recovery; indemnity; inconsistency; regulation

\section{INTRODUCTION}

The current asset recovery arrangements are widely implemented and proposed as an effort to recover the lost state finances as a result of corruption. This is particularly the case in the 2003 United Nations Convention against Corruption (UNCAC), which has been ratified by Law No. 7 of 2006 [1], that corruption crimes have now become transnational crimes, so the results of corruption crimes are easily moved from a country in which corruption occurs (locus delict) to another country that is considered a safe haven, which then turns into clean money after going through the money-laundering process. Therefore, mutual cooperation of each State party involved in the Convention in combating corruption through the recovery of assets is required.

Asset recovery is defined as the process of tracing, freezing, confiscating and returning to their country of origin funds that have been obtained through illegal means [2]. It is related to transnational crime. Corruption Eradication Commission (KPK) [3] provides a broader definition that asset tracking and recovery is a series of activities to search and trace the origins of assets owned by suspects, defendants, convicted persons and other related parties suspected as the result of corruption crime and/or money-laundering crime, and the return of it to the state [3].

Asset recovery can be pursued through both criminal and civil law mechanisms. Through both mechanisms it is done the return of state losses and the recovery of the country's economy [4]. Asset recovery through the criminal law in various literature is called "convicted based asset forfeiture" or "criminal forfeiture", whereas those through civil law mechanism is called "non convicted based forfeiture" or "civil forfeiture" or "objective forfeiture" or "in rem forfeiture"

In the law of eradication of corruption in Indonesia both of these asset recovery mechanism are regulated in Law Number 31 Year 1999 regarding Eradication of Corruption as amended by Law Number 20 Year 2001 regarding Amendment of Law Number 31 Year 1999 regarding the Eradication of Corruption. The asset recovery through a criminal law mechanism is provided for in Article 18 of Law Number 31 Year 1999, while the civil forfeiture mechanism is regulated in Articles 32, 33 and 34 of Law Number 31 Year 1999 and Article 38 C of Law Number 20 Year 2001.

However, in this paper we discuss the asset recovery through the criminal law as referred to in Article 18 of Law Number 31 Year 1999, specifically regarding the arrangement of replacement money payments. Article 18 of the Law cited shall read as follows:

(1) In addition to additional criminal offenses as referred to in the Criminal Code, as additional criminal are [5]:

Seizure of tangible or intangible goods or immovable goods used for or derived from corruption, including those owned by a convicted person in which a criminal act of corruption is committed, as well as from goods replacing the goods;

Payment of replacement money of an amount of money substantially equal to the amount of property acquired from corruption; 
Closing all or part of the company for a maximum period of 1 (one) year;

Revocation of all or part of certain rights or the deletion of all or any of the particular benefits which the Government may or may have provided to the convicted person.

(2) If the convicted fails to pay the replacement money as referred to in paragraph (1) letter $b$ within a period of 1 (one) month after the decision of the court that has obtained permanent legal force, then his/her property may be seized by the prosecutor and auctioned off to cover the replacement money.

(3) In the event that the convicted does not have sufficient property to pay the replacement money as referred to in paragraph (1) letter $\mathrm{b}$, he/she shall be punished with imprisonment that does not exceed the maximum threat of the principal penalty in accordance with the provisions of this Law and the duration the penalty is already determined in a court decision."

From the provisions of Article 18 of Law Number 31 Year 1999 , it can be seen there are two forms of asset recovery in the eradication of corruption, namely the confiscation of goods (used for or obtained from corruption) and the payment of replacement money (which amounts as much as the assets acquired from corruption). Regarding the payment of this substitute money is followed by further provisions as referred to in paragraph (2) and paragraph (3) of Article 18 of Law Number 31 Year 1999. The provision of paragraph (2) stipulates the seizure and the auction of the convicted property to cover the payment of the replacement money if within a month after the verdict in question has a permanent jurisdiction, the defendant shall not pay the substitute money. Whereas the provisions of paragraph (3) of it regulate the imposition of imprisonment (which shall not exceed the principal penalty) if the convicted person does not have sufficient property to pay the replacement money. If observed, the provision of paragraph (3) is "deliberately" has given an alternative to substitute the payment of the replacement money with imprisonment, although with a frill in the case of the convict does not have sufficient property to pay the replacement money, which is very potential to be manipulated.

Building on the above described facts, this paper is aimed at identifying imposition of indemnity payment regulation as a consequence of criminal act of corruption with imprisonment as regulated in Article 18 paragraph (3) of Law Number 31 Year 1999, which is in line with the concept of asset recovery and examining the fixed indemnity payment regulation that should be imposed in the form of asset recovery without being replaced by imprisonment.

\section{METHOD}

This study is a normative legal research conducted by making use of legal materials related to the rules of return of state assets that are illegally lost due to corruption crime. Statute approach and conceptual approach are used for the design of this study. The data were obtained from the literature study, covering legal documents governing the return of assets from confiscation by corruptors. Data were analyzed descriptively qualitatively.

\section{RESULT AND DISCUSSION}

\section{A. The Concept of Asset Recovery in Criminal Law}

The classical stream of criminal law rests on three pillars. First, the principle of legality which states that there is no criminal without law, no criminal act without law, and no prosecution without law; Secondly, the principle of guilty, namely that a person can only be liable to criminal acts committed by intentionally or by mistake. Thirdly, the principle of retaliation, namely that the criminal is not concretely charged with the intent to achieve something useful, but worth the weight or lightness of the deed done [6]. The latter is known as the Absolute Theory or Revenge.

It is difficult to deny that the birth of a legal principle is inseparable from the situation and conditions at that time. The legality principle which is reflected in the three pillars of the criminal law is aimed at protecting the interests of the individual (i.e. the human rights of the perpetrator of arbitrary of the law enforcer -author) as a feature main classical criminal law [7]. Whereas, the goal of modern criminal law is to protect the people from crime [7].

Related to the Absolute Theory or Revenge Theory, the English philosopher, reformer, and lawyer Jeremy Bentham, famous for his Utility Theory that emerged in the eighteenth century, argued that an important penal nature should be useful. There are three benefits of punishment. First, it will be useful to fix the offender. Second, punishment must eliminate the abuser's ability to commit a crime. Third, the penalty must give compensation to the injured party [8].

In Indonesia, the construction of the criminal law system developed in recent years still aims to reveal the criminal acts that occur, find the perpetrators and punish the perpetrators of criminal acts with criminal sanctions, especially imprisonment ("pidana penjara" and "pidana kurungan"). Meanwhile, issues of international legal development such as forfeiture and deprivation of criminal proceeds and instruments of crime have not been an important part of the criminal law system in Indonesia [8].

Therefore, in the context of the welfare-state teachings, the government is obliged to synergize law enforcement efforts based on the values of justice with the efforts of achieving national goals to realize the common prosperity for the community [8]. Based on such thoughts, the handling of criminal acts with economic motives must be done by using a fair approach for the community through returns on results and instruments of crime to the state for the benefit of the community. Finding and deprivation of criminal proceeds and instruments of crime not only displace some of the property of the perpetrators of crime to society, but also increase the likelihood of the community to realize a common goal of justice and prosperity for all members of society [8].

By following the aforementioned opinion, then if in corruption crime, the harmed party is the state (because the state money is corrupted by the perpetrator of corruption) 
which in turn the society also harmed because the state money that should be used for development the welfare of society becomes unrealized. Therefore, those convicted of corruption must provide compensation to the state, so that efforts to prosper from the community can be realized. Thus, circumstances (before occur the corruption crime) will be recovered, on the one hand, the perpetrators of corruption should have to be criminally responsible for their crimes, but on the other hand, the harmed state finances have been recovered with the payment of such compensation. This is actually the concept of asset recovery, whose implementation is done by using a fair approach from the perspective of society that is through the return of money/results obtained from a corruption to the state, for the sake of fulfillment of economic and social rights of society, which leads to public welfare.

\section{B. Criminal Sentencing of Replacement Money Payment as Asset Recovery}

The sentence of the payment of replacement money in the eradication of corruption in Indonesia is first stipulated in Law Number 31 Year 1999 regarding the Eradication of Corruption, that is Article 18 paragraph (1) letter b, paragraph (2) and paragraph (3) of it. Article 18 Paragraph (1) letter b of that Law determines: "In addition to additional sentence as referred to in the Book of Criminal Law, as an additional sentence shall be the payment of replacement money in the amount equal to the property obtained from the criminal act of corruption." Clearly this can be seen from the provisions of Article 18 paragraph (1) letter b of Law Number 31 Year 1999 that the payment of replacement money is an additional sentence, not a principal sentence.

The replacement money which is meant in Article 18 paragraph (1) letter b of Law Number 31 Year 1999 is replacement money from state losses arising as a result of a criminal act of corruption. In that article, it is determined that the payment of the replacement money as an additional sentence shall not be bigger than the being corrupted, because the amount shall be determined as much as the property derived from the criminal act of corruption [5].

Furthermore, in paragraph (2) of Article 18 of Law Number 31 Year 1999 it is determined that if the convicted person does not pay the replacement money as referred to in paragraph (1) letter $\mathrm{b}$ within a period of 1 (one) month after the court decision has obtained permanent legal power, then his/her property may be seized by the prosecutor and auctioned off to cover the replacement money. Subsequently to paragraph 3 of the same article, it is determined that in the event that the convicted person does not have sufficient property to pay the replacement money as referred to in paragraph (1) letter $b$, he shall be punished with imprisonment whose duration does not exceed the maximum threat of the main penalty accordingly with the provisions of Law Number 31 Year 1999 and the duration of imprisonment has determined in the court decision.

By looking at the systematic arrangement of additional penalties in the form of replacement money in Article 18 of Law Number 31 Year 1999, it can be seen that from the beginning the payment of this surrogate money stipulated as a non-physical penalty of replacement payments (as an asset recovery), due to corporal punishment has been determined in the principal punishment. If the convicted person does not pay the replacement money, all his possessions are confiscated and auctioned, so that the proceeds of the auction sale is used to cover the payment of the replacement money. At this point, it can be seen that the additional sentence for the payment of this replacement money is formulated as a form of recovery of assets from damaged state money (asset recovery). However, after being incorporated in the provisions of paragraph (3) of Article 18 of Law Number 31 Year 1999, the concept of punishment in the form of an asset recovery is changed to sanctions in the form of prison whose duration does not exceed the maximum limit of the Temporary Penalty Threat. While prison sentences (and penalty fines) have been subject to the basic penalties. In the end, people who feel they have an "option" not to pay a substitute but instead opt for a penalty instead of having to pay a substitute of just a few dollars, which should keep their wife and children for years). If it is like this, the state does not get its financial loss due to corruption in question, because the payment of state financial compensation is replaced by a person's jail sentence, and an inconsistent form of the rule of asset recovery.

Meanwhile, as described in Part II above, in corruption, there are always parties who are harmed, and the aggrieved party is the state. In the concept of asset recovery as described above, the convict in the case of corruption should compensate the state as a fair approach from a societal perspective, manifested by the payment of substitute money for state financial losses due to corruption. Thus the state's finances have been restored (recovery), so that it can be used for the fulfillment of socio-economic rights of the community whose purpose is to prosper from society. Therefore, in fact, the regulation on the payment of replacement money as an additional sentence as referred to in Article 18 paragraph (1) letter b and paragraph (2) of Law Number 31 Year 1999 has been in accordance with the concept of asset recovery but the provisions of paragraph (3) the article has canceled the concept of applied asset recovery.

By the "option" arrangement as referred to in paragraph (3) of Article 18 of Law Number 31 Year 1999, corruption offenders can prepare from the beginning, i.e. from the time of investigation, even since the criminal act of corruption is done, to hide the proceeds of their corruption crime, if necessary overseas, and he can freely keep it in many countries that are not participating in UNCAC 2003, as they do not ratify the UNCAC 2003. These States are not obligate and are not bound to comply with those 2003 UNCAC, namely to cooperate with the state's parties of those conventions to combat the corruption crime as a transnational crime.

This is very potential and very likely to be done by the perpetrators of corruption crime, considering the process of handling corruption from investigation, prosecution, and corruption criminal proceedings to obtain a permanent decision (inkracht van gewijsde) takes a relatively long time, reaching three years. It even becomes much longer if calculated since the criminal act of corruption is committed by the perpetrator. With a relatively long grace period, the perpetrators of corruption crime will be free to secure their proceeds of corruption crime, so that when execution of the payment of 
replacement money is made, it is seen that he/she has no sufficient assets to pay the replacement money for a number of their corruption proceeds, so to displace it, he must undergo a physical sentence in the form of imprisonment, which, because they are restricted shall not exceed the duration of the principal sentence, usually relatively short. In such cases, the offenders of corruption crime can calculate the profit from the proceeds of his corruption crime after being substituted by the imprisonment he undergoes. This is what actually causes eradication of corruption with this repressive approach to be very unproductive in terms of asset recovery perspective. It is no wonder that the Professor of International Criminal Law at Padjadjaran University, Romli Atmasasmita once said that the perpetrators of corruption often take refuge and benefit from the principle that "corruption is a low-risk and high-profit activity [9]."

Therefore, the provision of paragraph (3) of Article 18 of Law Number 31 Year 1999 should be omitted, because the execution of the criminal verdict is not limited by a certain time period, so execution of the payment of replacement money can be done at any time executor managed to track the existence of corruption assets that hidden through asset tracing. Alternatively, if a convicted person of corruption crime after leaving the prison (after undergoing principal sentence) and then have property, executor can perform further execution of payment of replacement money in question. Therefore, the provision of paragraph (3) should be omitted and replaced with the provision that in addition to the property of the convicted auctioned to cover the substitute but insufficient repayment, if in the future he/she possession or known to has possession of any other property, either when he/she still undergoing principal sentence or after completion of his/her sentence term, the property may be seized and auctioned by the prosecutor for the fulfillment of the payment of replacement money until all his/her obligation to pay the replacement money is fulfilled, either with one or more executions.

In regard with this, the additional sentence in the form of payment of replacement money shall remain an additional sentence as a form of asset recovery, not substituted into additional imprisonment. This will really give the deterrent effect to the corruptor himself not to repeat his actions, and also to other state or community officials never try to do so.

Even if required, it is possible to compare the value of the corruption asset between the values of an asset at the time of the occurrence of corruption crime with the value of the asset when executed at the current value of the currency. Therefore, possible is possible to impose a kind of "interest" or a penalty if using the standard value of money, because the value of money at the time of the occurrence of corruption with the execution time that takes many years, is probably not equivalent. The amount is the same but the value when executed tends to be smaller.

\section{CONCLUSIONS}

There is inconsistency in the arrangement of payment of replacement money as a form of asset recovery in the eradication of corruption in Indonesia as regulated in Article 18 paragraph (1) letter b, paragraph (2) and paragraph (3) of Law Number 31 Year 1999 concerning Eradication of Action Criminal Corruption, because the finalization of the arrangement (i.e., paragraph (3)) provides an opportunity to substitute the replacement payment (as an asset recovery) with imprisonment, so it is not in accordance with the concept of asset recovery.

The provisions of paragraph (3) of Article 18 of Law Number 31 Year 1999 regarding the Eradication of Corruption should be omitted and replaced by a provision stipulating that if after the convicted property is seized and auctioned to cover the replacement money as referred to in paragraph (2) of this article is insufficient, then if the convicted has again or is known to have other properties, the prosecutor is authorized to seize the auction of the property in question to cover the payment of the replacement money until the entire payment of the convicted replacement money fulfilled, either through one or more executions.

\section{ACKNOWLEDGEMENT}

The author would like to thank all the parties who have helped and contributed in the writing of this article, both those who contribute in the form of funding and critical ideas. Hopefully this paper can be useful theoretically and practically for the addition and development of knowledge, especially in the field of legal science.

\section{REFERENCES}

[1] Law Number 7 Year 2006 regarding Ratification of United Nations Convention Against Corruption, 2003

[2] Basel Institute on Governance, www.baselgovernance.org. accessed on January 17 th, 2018 at 12.30 PM.

[3] Komisi Pemberantasan Korupsi, Pemulihan Aset Dalam Tindak Pidana Korupsi dan Pencucian Uang, Presentation paper in Atmajaya University, Jogjakarta, September 28th, 2017.

[4] Muhammad Yusuf, Merampas Aset Koruptor Solusi Pemberantasan Korupsi di Indonesia, PT. Kompas Media Nusantara, Publisher, 2013.

[5] Law Number 31 Year 1999 regarding the Eradication of Corruption.

[6] Muladi and Barda Nawawi Arief, Teori-Teori Dan Kebijakan Pidana, Alumni Publisher, Bandung, 1992.

[7] Hiariej, E. O. S. Asas legalitas dan penemuan hukum dalam hukum pidana. Erlangga, 2009.

[8] Jeremy Bentham, Teori Perundang-undangan: Prinsip-Prinsip Legalisasi, Hukum Perdata dan Hukum Pidana, Penterjemah Nurhadi, Nuansa Publisher, Bandung, 2006.

[9] Romli Atmasasmita, Sekitar Masalah Korupsi Aspek Nasional Dan Aspek Internasional, CV. Mandar Maju Publisher, Bandung, 2004. 